CLINICAL STUDY

\title{
Changes in interleukin-6 and IGF system and their relationships in placenta and cord blood in newborns with fetal growth restriction compared with controls
}

\author{
Maria E Street ${ }^{1}$, Pietro Seghini ${ }^{1}$, Stefania Fieni ${ }^{2}$, Maria Angela Ziveri ${ }^{1}$, Cecilia Volta ${ }^{1}$, Davide Martorana ${ }^{3}$, \\ Isabella Viani $^{1}$, Dandolo Gramellini ${ }^{2}$ and Sergio Bernasconi ${ }^{1}$ \\ Departments of ${ }^{1}$ Pediatrics, ${ }^{2}$ Obstetrics and Gynecology, and ${ }^{3}$ Genetics, University of Parma, Via Gramsci, 14, 43100 Parma, Italy \\ (Correspondence should be addressed to M E Street; Email: mariaelisabeth.street@uniprit)
}

\begin{abstract}
Objectives: The IGF system is central to fetal growth. Recently, the relationships between cytokines and the IGF system have been shown in specific tissues. It is unknown whether these occur in the placenta. The aim of this study was to assess whether interleukin-6 (IL-6) modulated the IGF system.

Methods: Whole villous tissue and cord serum were collected from fetal growth restriction (FGR) neonates diagnosed before birth with altered Doppler velocimetry and controls. Sixteen FGR and 20 controls, born after week 32 of gestation from elective Caesarean sections, were compared. Total RNA was extracted from the placenta samples, reverse transcribed, and real-time quantitative reverse transcriptase (RT)-PCR was performed to quantify cDNA for IGF-I, IGF-II, IGF binding protein (IGFBP)1, IGFBP-2, and IL-6. The same proteins were assayed in placenta lysates and cord serum using specific commercial kits and western immunoblotting.

Results: FGR subjects had significantly more IGFBPs-1 and -2, and IL-6 mRNA and corresponding proteins in the placenta. In particular, the less phosphorylated isoforms of IGFBP-1 were highly increased. IL- 6 and IGFBPs-2 mRNA, and IL-6 and IGFBP-1 peptides were positively and significantly correlated in the placenta. The IGF-II peptide was also significantly increased in FGR placentas. In cord serum, IGFBPs-1 and -2 were significantly more elevated in the FGR neonates. Serum IL-6 was significantly and positively correlated with both IGFBP-1 and IGFBP-2.

Conclusions: The placenta of FGR neonates has higher IGF-II, IGFBP-1, IGFBP-2, and IL-6 contents compared with controls. At birth, IGFBPs-1 and -2 are increased in the cord blood of FGR neonates. IL6 and IGFBP-2 gene expressions are closely related in the placenta. We suggest that the increase in IL-6 and IGFBP-2 could be subsequent to hypoxia and nutrient deficiency. As IGFBP-2 has a strong affinity for IGF-II, which is crucial for fetal growth, it could be an important bioregulator of IGF-II in the placenta.
\end{abstract}

European Journal of Endocrinology 155 567-574

\section{Introduction}

Most cases of fetal growth restriction (FGR) are of unknown origin and therapeutic interventions to date are unsatisfactory (1). The interest in FGR has increased because approximately 13\% of these subjects do not have post-natal catch-up growth (2), and recently the so-called 'fetal origins of adult disease' and 'reprogramming' hypotheses have been developed to describe in utero modifications that might influence adult pathophysiology (3). The insulin-like growth factor (IGF)-IGF-binding protein (IGFBP) system is crucial for fetal growth, as experiments in knockout mice have shown $(4,5)$. IGF-II and the type-I IGF receptors are thought to be the key components of the IGF system for fetal growth (5).
Both IGFs-I and -II are synthesized in the placenta $(6,7)$. As the localization of IGFs and IGFBPs was similar, it was suggested that the IGFBPs regulated IGFs within the placenta (8). A further study (9) showed that IGF-II was more abundant than IGF-I throughout pregnancy, and IGFBPs- $1,-2,-4$, and -6 were expressed by all placenta cell types, while IGFBPs- 3 and -5 were expressed only by some of them. IGFBP-1 was the predominant binding protein in the decidua and was thought to be a good candidate to bind IGF-II synthesized by fetal trophoblasts, regulating its bioactivity (10). IGFBP-2 was abundant in the syncythiotrophoblast, and it was speculated that it might be of fetal origin (11). In growth-restricted fetuses, total serum IGFBP-1 concentrations and its phosphorylated isoforms have been reported to be increased. The less 
phosphorylated isoforms have reduced affinity for IGF-I and are thought to have a weaker growth-inhibiting or even a growth-promoting effect (12).

Cytokines are also thought to play an important role in placental development and growth, although they are poorly studied. The placenta produces pro-inflammatory cytokines, such as interleukin (IL)- 6 and TNF- $\alpha$ (13), and human decidua cells, in vitro, secrete IL-6, which increases markedly after stimulation with IL- $1 \alpha$, IL-1 $\beta$, and TNF- $\alpha$ (14). Very few data have been published in the fetus. Blood cultures stimulated with lipopolysaccharide $S$ show an increase in IL-6, IL-1 $\beta$, and TNF- $\alpha$ (15).

In recent years, cytokine and IGF-IGFBP interactions and relationships have been demonstrated, which are cell- and tissue-specific, and could also occur within the placenta. In transgenic mice, overexpressing IL-6 severely impaired growth associated with very low serum IGF-I concentrations was shown (16). We showed that in inflammatory bowel diseases in relapse, serum IL-6 and IGFBP-2 were increased and positively correlated (17). We also observed similar relationships in patients with cystic fibrosis, suggesting reduced IGF bioactivity (18). In caco-2 cells, we showed that both IL-1 and IL-6 reduced IGFBPs- 2 and -4 concentrations (19).

In humans, pre-eclampsia is characterized by both growth factor and cytokine modifications. In the placenta, IGF-II mRNA may be significantly reduced, whereas IGFBP-1 mRNA is increased compared with controls (20). Furthermore, several cytokines, such as TNF- $\alpha$ and IL-1 $\beta$, are increased (21). IGFBP-2 has been little investigated in the placenta and fetus, and relationships between IL- 6 and the IGF system have not been investigated earlier in the placenta and cord blood. This study was undertaken to investigate the IGF system in FGR more extensively and assess whether IL-6 plays a role in FGR and as modulator of the IGF system in the fetus and placenta.

\section{Materials and methods}

\section{Subjects and inclusion criteria}

Twenty FGRs and 29 appropriate gestational age (AGA) subjects were followed. Both FGR and control neonates were delivered by elective Caesarean section (CS). The causes of CS in the AGA newborns were: intra-hepatic colestasis in a woman who had undergone a previous CS; premature rupture of membranes with breech presentation and delivery within $4 \mathrm{~h}$ with no signs of infection; refusal of vaginal delivery for psychological reasons; and elective CS because of a previous CS. The cases with increased blood pressure, gestational diabetes, or reduced amniotic fluid were not included.

\section{Definition of appropriate for gestational age and fetal growth restricted births}

AGA births were defined on the basis of a normal birth weight $(<80$ th and $>10$ th percentile) with respect to the Italian standards (22), normal pregnancy, and the absence of maternal risk factors. All pregnancies were dated correctly by ultrasound during the first trimester of gestation. The FGR pregnancies were diagnosed by ultrasound according to the following criteria: abdominal circumference $<10$ th percentile and/or shift of fetal growth with the reduction of abdominal circumference compared with the measurement taken at the 20th week of gestation. The diagnosis of FGR was made within the 32nd week and was ascribed to a probable placental cause after excluding other causes, such as infections, chromosomal abnormalities, genetic syndromes, maternal malnutrition, substance abuse, gross placental abnormalities, and multiple fetuses. In FGR, Doppler velocimetry was altered in 18 out of the 20 cases in the placenta and/or fetus site.

\section{Investigations}

At birth, information on maternal age, birth weight of parents, maternal body mass index (BMI) before pregnancy and at delivery, previous gynecological history, medical history during pregnancy, fetal biophysical data (exact duration of pregnancy, growth trend, fetal and maternal Doppler velocimetry data in FGR, and non-stress test), clinical data at delivery (indication for CS, neonatal sex, weight, length, head circumference, Apgar score, acid-base equilibrium and perinatal data), and weight and macroscopic aspect of the placenta were collected.

\section{Study design}

Prior to the study, we analyzed physiological variations from week 35 to 40 of gestation, studying two groups of controls (group 1: 35-37 weeks of gestational age, $n=11$ and group 2: 38-40 weeks of gestational age, $n=15$ ) (23). On the basis of these results, we compared FGR cases with controls of comparable gestational age (FGR, $n=16$; controls, $n=20$; all born after 32 weeks of gestational age). The main features of the FGR and control subjects are shown in Table 1.

For correlation analysis, we analyzed FGR subjects and controls together and as separate groups. Relationships among mRNAs, proteins in the placenta, and corresponding proteins in the serum were studied. Only significant correlations were reported.

\section{Collection of biological material}

Umbilical vein samples were collected at birth from 18 out of the 20 FGRs and 29 controls. The blood was delivered to the laboratory within $20 \mathrm{~min}$, centrifuged 
Table 1 Main features at birth in fetal growth restriction (FGR) and control subjects.

\begin{tabular}{lcc}
\hline & FGR & Controls \\
\hline Males/females & $9 \mathrm{M} / 7 \mathrm{~F}$ & $10 \mathrm{M} / 10 \mathrm{~F}$ \\
Gestational age (weeks) & $35.3 \pm 0.5$ & $36.6 \pm 0.5$ \\
Weight of Placenta (g) & $337.6 \pm 34.4^{*}$ & $580.6 \pm 40.9$ \\
Weight at birth (kg) & $1.5 \pm 0.1^{*}$ & $2.8 \pm 0.1$ \\
Length at birth (cm) & $40.7 \pm 1.5^{*}$ & $49.2 \pm 0.4$ \\
Head circumference at birth (cm) & $29.1 \pm 0.9^{*}$ & $34.1 \pm 0.3$ \\
\hline
\end{tabular}

$\mathrm{M}$, male; $\mathrm{F}$, female. ${ }^{*} P<0.05$ versus controls.

$\left(2000 \mathrm{~g} / \mathrm{min}\right.$ for $10 \mathrm{~min}$ at $4{ }^{\circ} \mathrm{C}$ ), and the sera aliquoted and stored at $-80{ }^{\circ} \mathrm{C}$ until assayed. In 20 FGRs and 29 controls, four fragments of perifunicular villous tissue of approximately $5 \mathrm{~mm}^{3}$ were taken close to the fetal plate and rinsed repeatedly in sterile saline solution at $0{ }^{\circ} \mathrm{C}$. To standardize the storage conditions, fragments were treated immediately after washing with an RNase inhibitor (RNALater, Ambion, Austin, TX, USA), kept on ice, and placed at $-80^{\circ} \mathrm{C}$ within $15 \mathrm{~min}$. Areas including calcification and infarction were avoided. The perifunicular area was chosen, as analyses in our laboratory showed that this was the area richest in protein (data not shown).

\section{Isolation of RNA}

RNA extraction was performed using TRI-reagent (Sigma), according to the Chomczynski-Sacchi protocol (24). RNA integrity was verified by fractionating on $1 \%$ 3-(N-Morpholino) propanesulfonic acid (MOPS)-agarose gels, transferred onto nylon membranes, and then stained with methylene blue.

\section{cDNA synthesis}

cDNA was synthesized using $1 \mu \mathrm{g}$ total RNA sample according to the recommendations of the manufacturer (Applied Biosystems, Foster City, CA, USA). The retrotranscription reaction was initially evaluated with a qualitative method by the glyceraldehyde 3-phosphate dehydrogenase housekeeping gene amplification, using the following primers, which gave a PCR product of 555 bp (5'-GTGAAGGTCGGAGTCAACGGATTTGCT-3' and $5^{\prime}$-CACAGTCTTCTGAGTGGCAGTGATT- ${ }^{\prime}$ ).

\section{TaqMan assay on demand gene expression}

PCR was carried out using pre-designed primers and fluorescent probes (Assay on Demand, Applera). To normalize variables in gene expression, two control housekeeping genes were used, ubiquitin (UBQ) (assay ID: Hs00261902-m1) and 18S ribosomal RNA (assay ID: Hs99999901-s1) (25). Special attention was paid to selecting genes belonging to different functional classes, which reduced the chance that genes might be co-regulated.

Only threshold cycle (Ct) values $<40$ were used for the calculation of quantities. The reactions were performed in duplicate and the arithmetic mean of the two Cts was calculated. Fluorescent-specific probes amplified the cDNAs of the $18 \mathrm{~S}$ ribosome subunit and UBQ as internal control genes, and IGFs-I and -II, IGFBPs- 1 and -2 , and IL- 6 as genes of interest. IGF-I (assay ID: Hs00153126-m1), IGF-II (assay ID: Hs00171254-m1), IGFBP-1 (assay ID: Hs00426258-m1), IGFBP-2 (assay ID: Hs00167151 m1), and IL-6 (assay ID: Hs00174131-m1) probes were used according to the manufacturer's instructions.

Each gene was quantified on the same batch of cDNA to minimize experimental variation (25). Real-time quantitative RT-PCR was performed on a TaqMan ABI 7700 Sequence Detector System (Applied Biosystems). Each assay included a standard curve of four serial dilution points of SK-N-SH or IMR-32 cDNA (ranging from $50 \mathrm{ng}$ to $50 \mathrm{pg}$ ), a no-template control, and $25 \mathrm{ng}$ of each test cDNA. The efficiencies of all PCRs were above $95 \%$. The median coefficient of variation (based on calculated quantities) of duplicated samples was $6 \%$. The expression levels of other genes were normalized by dividing each sample by the highest value of gene expression.

\section{Total protein content}

The lysates were extracted using modified radioimmunoprecipitation (RIPA) buffer (Tris-HCL $50 \mathrm{mM}$; pH 7.4; NP40 1\%; Na-deoxycolate $0.25 \%$; NaCl $150 \mathrm{mM}$; EDTA $1 \mathrm{mM}$; PMSF $1 \mathrm{mM}$; aprotinin, leupeptin, and pepstatin $1 \mu \mathrm{g} ; \mathrm{Na}_{3} \mathrm{VO}_{4} 1 \mathrm{mM}$; NaF $1 \mathrm{mM}$ as protease inhibitors). The lysates were stored at $-80^{\circ} \mathrm{C}$ until assayed. The total protein content was determined using the "microassay Bio-Rad' protocol (Bio-Rad). Briefly, a standard curve was prepared using bovine albumin (Bio-Rad). To determine the concentration, the dye was added to each sample and standard and the absorbance was read at $570 \mathrm{~nm}$. The total protein content was expressed in micrograms per milligrams of placenta.

\section{Protein assays}

Total IGF-I was measured using RIA (Nichols Institute Diagnostics, CA, USA). Prior to assaying, serum samples were acid-ethanol precipitated to avoid interference of binding proteins. IGF-II was measured using IRMA (Diagnostic System Laboratories, Inc. Webster, TX, USA). Total IGFBP-1 was measured using ELISA (Diagnostic System Laboratories). Non-phosphorylated (Np) IGFBP1 was measured using IEMA (Medix Biochemica, Kuniainen, Finland) (12). IGFBP-2 was assayed using RIA (Diagnostic System Laboratories). IL-6 was measured using ultrasensitive ELISA (Quantikine HS, R\&D Systems, Minneapolis, MN, USA). 
Immunoprecipitation, SDS-PAGE and immunoblotting of IGFBP-2 and $\mathrm{L}-6$

For immunoprecipitation, equal amounts of placenta lysates (1 mg total protein) were subjected to immunoprecipitation overnight at $4{ }^{\circ} \mathrm{C}$ using $1 \mu \mathrm{g}$ specific antibodies, anti-IGFBP-2 (Upstate Biotechnology, Lake Placido, NY, USA), and anti-IL-6 (Santa Cruz Biotechnology, Santa Cruz, CA, USA). The resulting immunocomplexes were adsorbed to protein-A/G Sepharose beads overnight at $4{ }^{\circ} \mathrm{C}$ as recommended by the manufacturer, then eluted with electrophoresis sample buffer (Invitrogen), and loaded on to $12.5 \%$ acrylamide gels (24). Normal human serum, and rhIGFBP-2 (approx. $31 \mathrm{kDa}$; GroPep, Adelaide, Australia) were used as positive controls. The proteins were then transferred to nitrocellulose membranes and probed with specific antibodies against IGFBP-2 (Upstate Biotechnology) and IL-6 (Santa Cruz Biotechnology) at $4{ }^{\circ} \mathrm{C}$ overnight. The bands were visualized by ECL (Amersham) using horseradish peroxidase-labeled anti-rabbit IgG (Amersham) as the second antibody to verify possible different molecular forms of peptides. The changes in IGFBP band intensity were evaluated using the Imaging Densitometer BIORAD GS-670 (Bio-Rad), expressed in optic densitometry units (ODU) and used as such for statistical analysis. As we did not find different molecular forms of IL-6, these data are not reported.

\section{Ethical approval}

Informed consent was obtained from the mothers as appropriate. The study was approved by the local Ethics Committee (University of Parma Medical School).

\section{Statistical analysis}

Statistical analyses were performed using SPSS 12.1 for Windows. The normal distribution of the data was determined using the Kolmogorov-Smirnov test. The data were analyzed using one-way ANOVA. IL- 6 and IGFBP-1 were not normally distributed and were analyzed using Kruskal-Wallis ANOVA. The correlation analysis was performed using Pearson's or Spearman's linear regression analyses as required. $P<0.05$ was considered statistically significant. The data are expressed as mean \pm s.E.M. unless otherwise stated.

\section{Results}

\section{Comparison of fetal growth restriction with controls}

Gene expression in the placenta In the placenta, in FGR and controls, IGF-I mRNA and IGF-II mRNA contents were similar. IGFBP-1 mRNA was more elevated in FGR, but the range of variability was very high and statistical significance was not attained. IGFBP-2 mRNA was increased in FGR compared with controls $(P<0.05)$. IL-6 mRNA was also increased in FGR compared with controls $(P<0.05$, Fig. 1$)$.

Corresponding proteins in the placenta Total protein content of placenta was similar in FGR and controls $(33.7 \pm 5.2$ vs $36.9 \pm 5.9 \mu \mathrm{g} / \mathrm{mg}$, n.s. $)$. In the placenta lysates, IGF-I was undetectable in almost all cases. IGF-II was higher in FGR compared with controls as well as total IGFBP-1 and IL-6 $(P<0.05)$. Np-IGFBP-1 was also significantly higher in FGR compared with controls. IGFBP-2 was almost double in FGR compared with controls, but statistical significance was not attained (Table 2).

IGFBP-2 in the placenta, studied by western immunoblotting, showed that IGFBP-2 had two major molecular forms in the placenta of 30 and $23 \mathrm{kDa}$, respectively, both in FGR and controls. The $30 \mathrm{kDa}$ fragment was significantly increased in FGR placentas

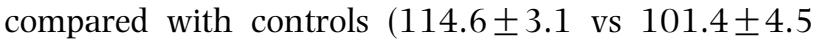
ODU), whereas the amount of the $23 \mathrm{kDa}$ fragment was similar in both groups. Furthermore, the $30 \mathrm{kDa}$ fragment was increased in FGR compared with the $23 \mathrm{kDa}$ fragment $(114.6 \pm 3.1$ vs $103.7 \pm 6.1$ ODU, n.s.), whereas the amount of the two fragments was similar in controls $(101.4 \pm 4.5$ and 101.9 \pm 6.3 ODU, respectively; Fig. 2).

Cord blood In cord serum, IGF-I concentrations were similar in FGR and controls $(51.5 \pm 9.5$ and $54.4 \pm$ $7.9 \mathrm{ng} / \mathrm{ml}$, respectively), while IGF-II was lower in FGR

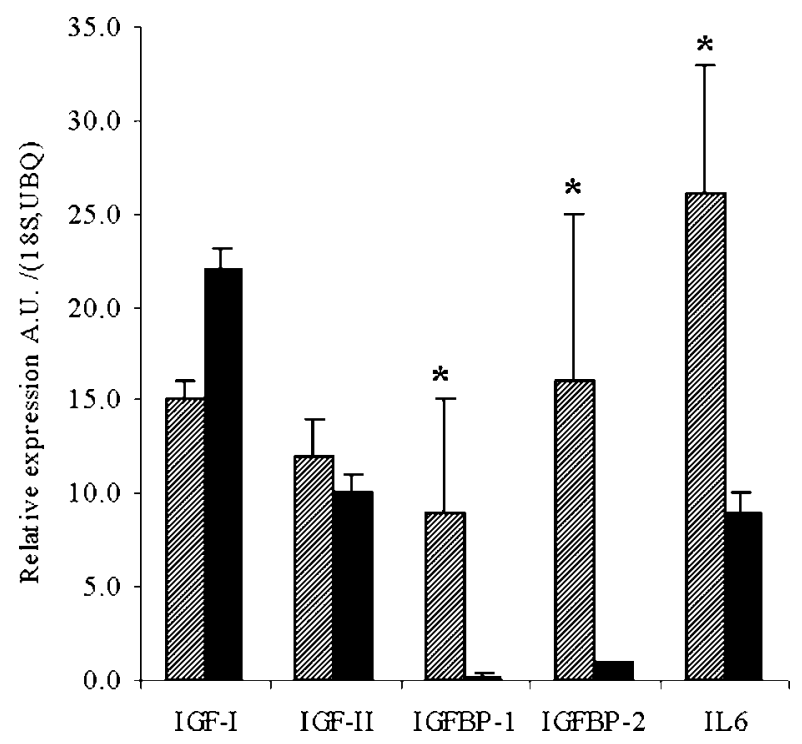

Figure 1 Relative expression of the IGFs-I and -II, IGFBPs-1 and -2, and IL-6 genes with respect to 18 S ribosomal RNA and ubiquitin gene expression in arbitrary units. The hatched bars represent the fetal growth restricted (FGR) cases and the solid bars represent the control cases. IGF, insulin-like growth factor; IGFBP, IGF binding protein; IL, interleukin; UBQ, ubiquitin ${ }^{\star} P<0.05$ versus controls. 
Table 2 Insulin-like growth factors (IGFs)-I and -II, IGF binding protein (IGFBP)-1, non-phosphorylated (Np)-IGFBP-1, IGFBP-2, and interleukin (IL)-6 proteins in the placenta in fetal growth restricted (FGR) and control newborns.

\begin{tabular}{lcc}
\hline & FGR & Controls \\
\hline IGF-II (ng/mg) & $167.6 \pm 9.3^{*}$ & $131.7 \pm 7.5$ \\
Total IGFBP-1 $(\mathrm{ng} / \mathrm{mg})$ & $72.2 \pm 17.8^{*}$ & $25.8 \pm 8.4$ \\
Np-IGFBP-1 $(\mathrm{ng} / \mathrm{mg})$ & $123.3 \pm 38.7^{*}$ & $37.1 \pm 17$ \\
IGFBP-2 $(\mathrm{ng} / \mathrm{mg})$ & $140.3 \pm 30.7$ & $79.1 \pm 13.2$ \\
IL-6 $(\mathrm{pg} / \mathrm{mg})$ & $68.3 \pm 8.8^{*}$ & $43.7 \pm 4.5$ \\
\hline
\end{tabular}

${ }^{*} P<0.05$ versus controls. Proteins are nanograms or picograms per milligram of placenta.

(497.4 \pm 24.7 vs $612.2 \pm 29.2 \mathrm{ng} / \mathrm{ml}, P<0.05$, Fig. 3 ). Total IGFBPs- 1 and -2 were higher in the FGR neonates $(159.2 \pm 38.4 \mathrm{ng} / \mathrm{ml}$ and $2366.4 \pm 408.1 \mathrm{ng} / \mathrm{ml}$ vs $70.1 \pm 20.3 \mathrm{ng} / \mathrm{ml}$ and $1322.1 \pm 119.2 \mathrm{ng} / \mathrm{ml}$, respectively, $P<0.05)$. Np-IGFBP-1 was also increased in FGR compared with controls $(171.6 \pm 34 \mathrm{ng} / \mathrm{ml}$ vs $63.4 \pm$ $14 \mathrm{ng} / \mathrm{ml}, P<0.05$ ) (Fig. 3). Serum IL-6 was similar in the two groups $(3.6 \pm 0.9 \mathrm{pg} / \mathrm{ml}$ in FGR and $3.6 \pm 0.8 \mathrm{pg} / \mathrm{ml}$ in controls).

\section{Correlation analysis}

In the placenta In all subjects, IGFBP- 2 mRNA was positively correlated with IL- 6 mRNA $(R=0.67$,

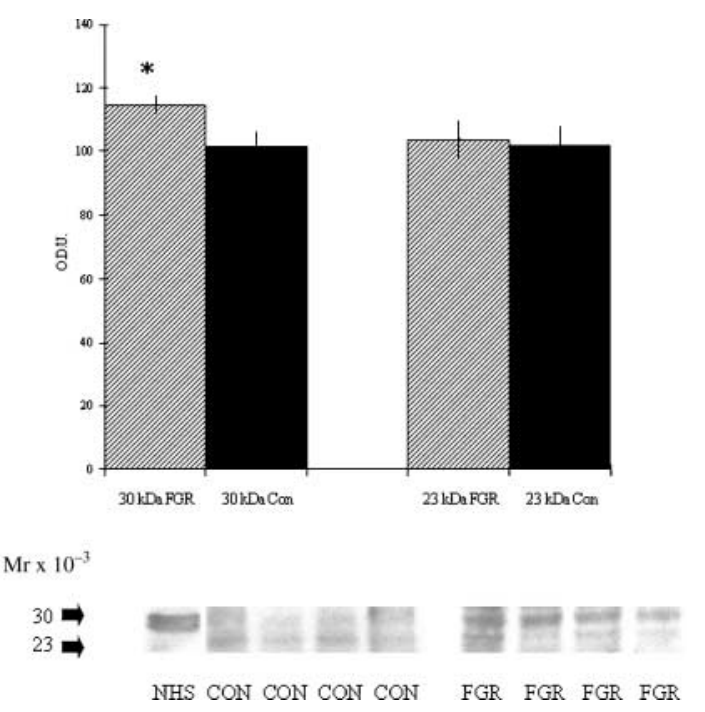

Figure 2 Quantity of individual insulin-like growth factor binding protein (IGFBP)-2 fragments, in optic densitometry units (O.D.U) in the upper panel and representative IGFBP-2 immunoblot in the lower panel. In the upper panel, the hatched bars represent the fetal growth restricted (FGR) cases and the solid bars represent the control cases for each individual fragment observed in the immunoblots. The molecular weights of the bands estimated relative to the mobility of the standards (Amersham) are shown on the left-hand side of the blot. Normal human serum (NHS) was used as the positive control. ${ }^{*} P<0.05$.

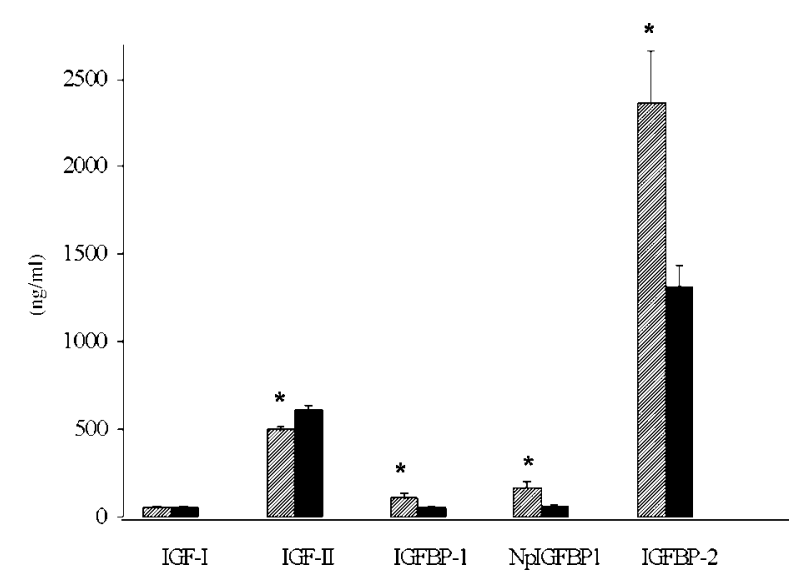

Figure 3 Insulin-like growth factors (IGFs)-I and -II, IGF binding protein (IGFBP)-1, non-phosphorylated (Np) IGFBP-1, and IGFBP2 in serum from cord blood in fetal growth restricted (FGR) newborns and controls appropriate for gestational age. The hatched bars represent the FGR and the solid bars represent the control cases. Proteins are $\mathrm{ng} / \mathrm{mg}$ placenta. ${ }^{*} P<0.05$ versus controls.

$P<0.05$; Fig. 4). This correlation was present in the subgroup of controls $(R=0.60, P<0.05)$, but not in the FGR group alone. With regard to the corresponding proteins in the placenta, total IGFBP-1 and IL- 6 were positively correlated $(R=0.69, P<0.05)$ in the whole group and individual subgroups.

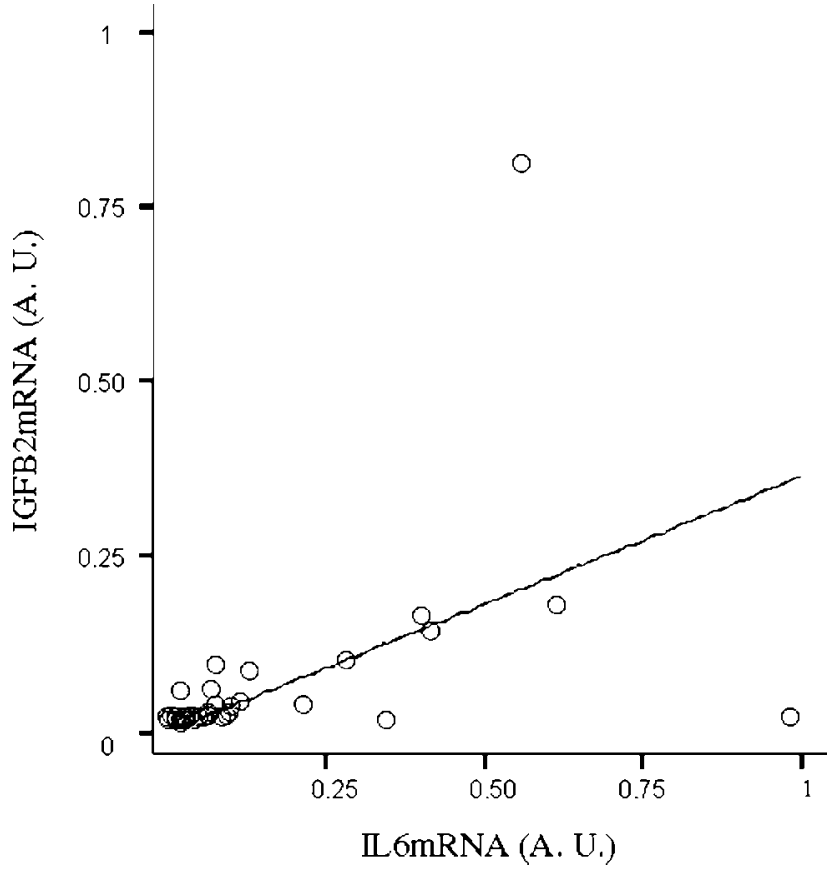

Figure 4 Expression of interleukin (IL)-6 and insulin-like growth factor binding protein (IGFBP)-2 genes in the human placenta. Gene expression is expressed in arbitrary units and is assessed by quantitative real-time RT-PCR, relative to two housekeeping genes (18S ribosomal RNA and ubiquitin). IL-6 and IGFBP-2 mRNAs are significantly and positively correlated $(R=0.67, P=0.03)$. 
In cord blood In the whole group, total IGFBP-1 and IGFBP- 2 were positively correlated with IL- $6(R=0.50$ and $0.48, P<0.05$, respectively). Np-IGFBP-1 was similarly correlated with IL-6 $(r=0.51, P<0.05)$. Total IGFBPs- 1 and -2 were also positively correlated $(r=0.69, P<0.05)$.

\section{Discussion}

This study evaluates IL- 6 and the IGF system in human placenta and cord serum showing that IL-6 is significantly changed in FGR neonates. Furthermore, IL-6 and IGFBP-2 gene expression were closely related in the placenta.

IGF-I gene expression was high in the placenta, but the corresponding protein was undetectable in almost all cases. Few earlier studies have shown IGF-I secretion by the human placenta, only describing very low concentrations using organ cultures (26) or immunostaining $(8,27)$. All other publications have studied IGF-I gene expression mainly using in situ hybridization $(9,11)$. Our method was not sufficiently sensitive to detect the IGF-I peptide. However, since the gene expression was high, this may suggest post-transcriptional and/or translational modifications that are yet unknown. We did not detect any significant difference in IGF-I mRNA in FGR compared with controls, as in the study by Abu-Amero et al. (28) and in contrast with earlier studies, which showed an increase, but investigated term births (29) or used IGF-I immunostaining in as many as three placentas (30).

Cord serum IGF-I was not significantly different in FGR and controls, which reflects the findings in animal model studies (30), but is in contrast with the data published earlier in humans (31). However, these authors studied subjects delivered after the 38th week of gestation by both CS and vaginal delivery.

The IGF-II peptide was increased in the placenta in FGR, but not IGF-II mRNA. Data in growth-restricted guinea pigs from uterine artery ligation confirm unchanged IGF-II mRNA in the placenta (32). There are no data in humans with which we can make comparisons. Cord serum IGF-II was significantly reduced in the FGR newborns as reported earlier by Holmes et al. (33) and Leger et al. (34), but in contrast with the study on serum from direct puncture of umbilical cords, which showed unchanged IGF-II in FGR (35).

A significant increase in IGFBP-1 mRNA and corresponding peptide in the placenta was previously reported. This finding matches data in animal studies. All these studies are in favor of the growth inhibitory effect of IGFBP-1 (36). However, we identified the less phosphorylated isoforms of IGFBP-1 as the most increased, which is in contrast with the data published previously describing similar levels of Np-IGFBP-1 in appropriate and small-for-gestational-age fetuses at birth (12). Thus, we speculate that our finding might reflect a protective and compensatory mechanism in FGR consistent with the increased IGF-II concentrations observed in placenta lysates.

Abnormal placental blood circulation may be associated with variable degrees of hypoxia and deficient nutrient supply to the fetus. It is still unknown which mechanisms in the human fetus increase total and Np-IGFBP-1, although some have been suggested (37-39). IGFBP-1 concentrations in cord serum may be increased in FGR (10), as we confirmed. A study in discordant twins with reduction in the supply of essential and non-essential amino acids to the FGR twins showed increased fetal levels of IGFBP-1 (39), suggesting a link between reduced nutrient supply and changes in growth factors.

IGFBP-2 was a highly expressed gene, being the most increased IGFBP both in the placenta and cord serum. This is in contrast with an earlier study based on histochemistry findings, which speculated that placental IGFBP-2 was probably of fetal origin (9). Increased IGFBP-2 gene expression and concentrations in the placenta and fetus suggest blunted IGF bioactivity. Many studies have suggested that IGF-II is the most important IGF for fetal growth $(4,5)$. Intact IGFBP-2 has special affinity for IGF-II and an inhibiting effect on this peptide. Interestingly, IGFBP-2 has more than one molecular form in the human placenta. IGFBP-2 proteolysis has been reported recently in serum, and some IGFBP-2 fragments have demonstrated binding capacity (40). Recently, different IGFBP-2 fragments have been described in human plasma with a smaller affinity for IGF-II than intact IGFBP-2 (41). We do not know the affinity of the IGFBP-2 fragment for IGF-II in the placenta. However, in FGR, the intact IGFBP-2 was the most increased, compatible with the IGF-inhibitory action of this peptide.

Reported data on the possible effects of hypoxia on IGFBP-2 are contrasting (32). We detected a significant increase in cord serum IGFBP-2 in FGR newborns, but the mechanisms underlying this observation are unknown. IL-6 mRNA was increased in the placenta of FGR neonates. Placenta IL- 6 concentrations were elevated compared with serum concentrations in pregnant and non-pregnant adults (17), suggesting that this cytokine might play a role in pregnancy. Recently, it has been shown in trophoblast cells that hypoxia increased IL- 6 production (42), and protein calorie malnutrition is a cause of increased IL-6 production by peripheral blood mononuclear cells (43). It could be speculated that the increase in IL-6 mRNA and the corresponding protein could be subsequent to hypoxia and/or nutrient deficiency secondary to altered blood flow in the placenta.

In addition, we reported data suggestive of a close relationship between IL- 6 and IGFBP-2 gene expression. We detected similar relationships in the corresponding serum proteins in inflammatory bowel diseases and 
cystic fibrosis patients. These findings suggested that IGFBP-2 reacted as an acute phase protein $(17,18)$. Possibly, IL-6 regulates IGFBP-2 gene expression or there is a common factor upregulating both genes. In conclusion, this study offers a new insight into IGFIGFBP and IL-6-IGFBP relationships within the human placenta and fetus and suggests an important role of IGFBP-2 and IL-6. Finally, we speculate that in FGR pregnancies, hypoxia and/or limited substrate availability might determine an increase in IL-6 with a simultaneous or subsequent increase in IGFBP-2 within the placenta. This could have a predominant inhibiting effect on IGF-II, although IGF-II and Np-IGFBP-1 increase as a protective mechanism. This represents a new working hypothesis, and the role of IL- 6 might offer possible therapeutic implications.

\section{Acknowledgements}

This study was supported by a grant from the Ministry of Education, University and Research in Italy (20032004). Preliminary data were presented as abstracts at the Endocrine Society 87th Annual meeting, 4-7 June 2005, San Diego, CA, USA, the ESPE/LWPES 7th joint meeting, 21-24 September 2005, Lyon, France, and at the XV Italian National Society for Endocrinology Meeting, 13-15 October 2005, Cagliari, Italy (award winning abstract as the best clinical presentation). We are indebted to Prof T M Neri for precious advice on the real-time PCR study, and Prof A Bacchi-Modena for his support. We thank Prof S Cianfarani for helpful revision of this manuscript. Finally, we thank Dr Rossana di Marzio for all her help with administrative work related to this research.

\section{References}

1 Resnik R. Intrauterine growth restriction. Obstetrics and Gynecology 200299 490-496.

2 Karlberg J \& Albertsson-Wikland K. Growth in full-term small-forgestational-age infants: from birth to final height. Pediatric Research 199538 733-739.

3 Godfrey KM \& Barker DJ. Fetal nutrition and adult disease. American Journal of Clinical Nutrition 200071 1344S-1352S.

4 DeChiara TM, Robertson EJ \& Efstratiadis A. A growth-deficient phenotype in heterozygous mice carrying an insulin-like growth factor-II gene disrupted by targeting. Nature $199034478-80$.

5 Liu JP, Baker J, Perkins AS, Robertson EJ \& Efstratiadis A. Mice carrying null mutations of the genes encoding insulin-like growth factor-I (IGF-I) and Type-1 IGF Receptor (Igflr). Cell 199375 59-72.

6 Shen SJ, Wang C-Y, Nelson KK, Jansen M \& Ilan J. Expression of insulin-like growth factor II in human placentas from normal and diabetic pregnancies. PNAS 198683 9179-9182.

7 Wang C-Y, Daimon M, Shen S-J, Engelman GL \& Ilan J. Insulin-like growth factor-I messenger ribonucleic acid in the developing human placenta and in term placenta of diabetics. Molecular Endocrinology $19882217-229$.
8 Hill DJ, Clemmons DR, Riley SC, Bassett N \& Challis JRG. Immunohistochemical localization of Insulin-like growth factors (IGFs) and IGF binding proteins-1, -2 , and -3 in human placenta and fetal membranes. Placenta 199314 1-12.

9 Han VKM, Bassett N, Walton J \& Challis JRG. The expression of insulin-like growth factor (IGF) and IGF-Binding Protein (IGFBP) genes in the human placenta and membranes: evidence for IGFIGFBP interactions at the feto-maternal interface. Journal of Clinical Endocrinology and Metabolism 199681 2680-2693.

10 Chard T. Insulin-like growth factors and their binding proteins in normal and abnormal human fetal growth. Growth Regulation 19944 91-100.

11 Han VKM \& Carter AM. Spatial and temporal patterns of expression of messenger RNA for insulin-like growth factors and their binding proteins in the placenta of man and Laboratory animals. Placenta 200021 289-305.

12 Kajantie E, Dunkel L, Rutanen E-M, Seppala M, Koistinen R, Sarnesto A \& Andersson S. IGF-I, IGF binding protein (IGFBP)-3, phosphoisoforms of IGFBP-1, and postnatal growth in very low birth weight infants. Journal of Clinical Endocrinology and Metabolism 200287 2171-2179.

13 Dudley DJ, Trautman MS, Araneo BA, Edwin SS \& Michell MD. Decidual cell biosynthesis of interleukin-6: regulation by inflammatory cytokines. Journal of Clinical Endocrinology and Metabolism $199274884-889$.

14 Meisser A, Cameo P, Islami D, Campana A \& Bischof P. Effects of interleukin-6 (IL-6) on cytotrophoblastic cells. Molecular Human Reproduction $199951055-1058$.

15 Dembinski J, Behrendt D, Martini R, Heep A \& Bartmann P. Modulation of pro-and anti-inflammatory cytokine production in very preterm infants. Cytokine 200321 200-206.

16 De Benedetti F, Alonzi T, Moretta A, Lazzaro D, Costa P, Poli V \& Martini A. IL-6 causes growth impairment in transgenic mice through a decrease in insulin-like growth factor-I: a model for stunted growth in children with chronic inflammation. Journal of Clinical Investigation $199799643-650$.

17 Street ME, Camacho-Hubner C, de'Angelis GL, Ziveri M, Giovannelli G, Bernasconi S \& Savage MO. The insulin-like (UGF)-IGF binding protein (IGFBP) system is modulated by interleukin-1 $\beta$ and interleukin- 6 in chronic inflammatory bowel disease. Hormone Research 200461 159-164.

18 Street ME, Ziveri MA, Spaggiari C, Viani I, Volta C, Grzincich GL, Virdis R \& Bernasconi S. Inflammation is a modulator of the IGFIGFBP system inducing reduced bioactivity of IGFs in cystic fibrosis. European Journal of Endocrinology $2006 \mathbf{1 5 4} 47-52$.

19 Street ME, Miraki-Moud F, Sanderson IR, Savage MO, Giovannelli G, Bernasconi S \& Camacho-Hubner C. Interleukin$1 \beta$ (IL-1 $\beta$ ) and IL-6 modulate insulin-like growth factor binding protein (IGFBP) secretion in colon cancer epithelial (caco-2) cells. Journal of Endocrinology $2003 \mathbf{1 7 9} 405-415$.

20 Shin JC, Lee JH, Yang DE, Moon HB, Rha JG \& Kim SP. Expression of insulin-like growth factor-II and insulin-like growth factor binding protein-I in the placental basal plate from pre-eclamptic pregnancies. International Journal of Gynaecology and Obstetrics $200381273-280$.

21 Grimble RF. Inflammatory status and insulin resistance. Current Opinion in Clinical Nutrition and Metabolic Care 20025 551-559.

22 Gagliardi L, Macagno D, Pedrotti D, Coraiola M, Furlan R, Agostinis L \& Milani S. Weight, length, and head circumference at birth of a North-eastern Italian population. Report of the ad hoc committee of the Italian Society of Neonatology. Italian Journal of Paediatrics 199925 159-169.

23 Chomczynski P. A reagent for the single-step simultaneous isolation of RNA, DNA and proteins from cell and tissue samples. Biotechniques 199315 532-534, 536-537.

24 Vandesompele J, De Preter KD, Pattyn F, Poppe B, De Paepe A \& Speleman F. Accurate normalization of real-time quantitative RT-PCR geometric averaging of multiple internal control genes. Genome Biology 20023 (research0034.Epub2002 Jun 18).

25 Street ME, Seghini P, Fieni S, Ziveri MA, Volta C, Martorana D, Viani I, Bernasconi S. IL-6 and IGFBP-2 are increased in IUGR, 
and greater in symmetric (early onset) IUGR both in the placenta and cord serum. The Endocrine Society 87th Annual meeting, 4-7 June 2005; P2-P41 (Abstract).

26 Sorem KA \& Siler-Khodr TM. Placental IGF-I in severe intrauterine growth retardation. Journal of Maternal-Fetal Medicine 1998 7 1-7.

27 Dalcik H, Yardimoglu M, Vural B, Dalcik C, Filiz S, Gonca S, Koktutk S \& Ceylan S. Expression of insulin-like growth factor in the placenta of intrauterine growth-retarded human fetuses. Acta of Histochemistry $2001 \mathbf{1 0 3}$ 195-207.

28 Abu-Amero SN, Ali Z, Bennett P, Vaughan JL \& Moore GE. Expression of the insulin-like growth factors and their receptors in term placentas: a comparison between normal and IUGR births. Molecular Reproduction and Development $199849229-235$.

29 Sheikh S, Satoskar P \& Bhartiva D. Expression of insulin-like growth factor-I and placental growth hormone mRNA in placenta: a comparison between normal and intrauterine growth retardation pregnancies. Molecular Human Reproduction 20017 287-292.

30 Roberts CT, Owens JA, Carter AM, Harding JE, Austgulen R \& Wlodek M. Insulin-like growth factors and foetal programming - a workshop report. Placenta 200324 S71-S75.

31 Cianfarani S, Germani D, Rossi P, Rossi L, Germani A, Ossicini C, Zuppa A, Argirò G, Holly JM \& Branca F. Intrauterine growth retardation: evidence for the activation of the insulin-like growth factor (IGF)-related growth-promoting machinery and the presence of a cation-independent IGF binding protein-3 proteolytic activity by two months of life. Pediatric Research $1998 \mathbf{4 4}$ 374-380.

32 Carter AM, Kingston MJ, Han KK, Mazzuca DM, Nygard K \& Han VK. Altered expression of IGFs and IGF-binding proteins during intrauterine growth restriction in guinea pigs. Journal of Endocrinology $2005 \mathbf{1 8 4} 179-189$.

33 Holmes R, Montemagno R, Jones J, Preece M, Rodeck C \& Soothill P. Fetal and maternal plasma insulin-like growth factors and binding proteins in pregnancies with appropriate or retarded fetal growth. Early Human Development 199749 7-17.

34 Leger J, Oury JF, Noel M, Baron S, Benali K, Blot P \& Czernichow P. Growth factors and intrauterine growth retardation. I. Serum growth hormone, insulin-like growth factor (IGF)I, IGF-II, and IGF binding protein 3 levels in normally grown and growth-retarded human fetuses during the second half of gestation. Pediatric Research $1996 \mathbf{4 0} 94-100$.

35 Lassarre C, Hardouin S, Daffos F, Forestier F, Frankenne F \& Binoux M. Serum insulin-like growth factors and insulin-like growth factor binding proteins in the human fetus. Relationships with growth in normal subjects and in subjects with intrauterine growth retardation. Pediatric Research 199129 219-225.

36 Watson CS, Bialek P, Anzo M, Khsravi J, Yee SP \& Han VK. Elevated circulating insulin-like growth factor binding protein-1 is sufficient to cause fetal growth restriction. Endocrinology 2006 147 1175-1186.

37 Popovici RM, Lu M, Bhatia S, Faessen GH, Giaccia AJ \& Giudice LC. Hypoxia regulates insulin-like growth factor-binding protein 1 in human fetal hepatocytes in primary culture: suggestive molecular mechanisms for in utero fetal growth restriction caused by uteroplacental insufficiency. Journal of Clinical Endocrinology and Metabolism $2001862653-2659$.

38 Kajimura S, Aida K \& Duan C. Insulin-like growth factor-binding protein-1 (IGFBP-1) mediates hypoxia-induced embryonic growth and developmental retardation. PNAS 2005102 1240-1245.

39 Bajoria R, Sooranna SR, Ward S \& Hancock M. Placenta as a link between amino acids, insulin-IGF axis, and low birth weight: evidence from twin studies. Journal of Clinical Endocrinology and Metabolism 200287 308-315.

40 Standker L, Kubler B, Obendorf M, Braulke T, Forssmann WG \& Mark S. In vivo processed fragments of IGF binding protein-2 copurified with bioactive IGF-II. Biochemical and Biophysical Research Communications $2003 \mathbf{3 0 4} 708-713$.

41 Mark S, Kubler B, Honing S, Oesterreicher S, John H, Braulke T, Forssman WG \& Standker L. Diversity of human insulin-like growth factor (IGF) binding protein-2 fragments in plasma: primary structure, IGF-binding properties, and disulfide bonding pattern. Biochemistry $2005443644-3652$.

42 Bowen RS, Gu Y, Zhang Y, Lewis DF \& Wang Y. Hypoxia promotes IL- 6 and -8 but reduces interleukin-10 production by placental trophoblast cells from preeclamptic pregnancies. Journal of the Society for Gynecological Investigation 200512 428-432.

43 Malave I, Vethencourt MA, Chacon R, Quinones D, Rebrij C \& Bolivar G. Production of interleukin-6 in cultures of peripheral blood mononuclear cells from children with primary proteincalorie malnutrition and from eutrophic controls. Annals of Nutrition and Metabolism 199842 266-273.

Received 26 April 2006

Accepted 10 July 2006 